\title{
O cotidiano revelado na poesia de Adélia Prado
}

Adilson Citelli ${ }^{1}$

Possui graduação em Letras (1973), mestrado em Literatura Brasileira (1982) e doutorado em Literatura Brasileira (1990), todos pela Universidade de São Paulo. É professor titular do Departamento de Comunicações e Artes da ECA/USP e dos programas de graduação e pós-graduação, onde ministra cursos e orienta dissertações e teses nas áreas de Comunicação e Linguagem, com ênfase nas subáreas: comunicação/educação, comunicação/linguagem. É co-editor da revista Comunicação \& Educação².

E-mail: citelli@uol.com.br

Natural de Divinópolis, Minas Gerais, Adélia Prado nasceu no dia 13 de dezembro de 1935, filha de João do Prado Filho, ferroviário, e de Ana Clotilde Corrêa. Seus primeiros versos foram motivados pela morte da mãe, em 1950. No ano seguinte, iniciou o curso de Magistério na Escola Normal Mário Casassanta e o concluiu em 1953. Dois anos mais tarde, começou a lecionar no Ginásio Estadual Luiz de Mello Viana Sobrinho.

Em 1958 casou-se, em Divinópolis, com José Assunção de Freitas, funcionário do Banco do Brasil. Dessa união nasceram cinco filhos. Em 1972 morreu seu pai e, em 1973, formou-se em Filosofia juntamente com o marido, na Faculdade de Filosofia, Ciências e Letras de Divinópolis. Nessa ocasião, enviou carta e originais de seus novos poemas ao poeta e crítico literário Affonso Romano de Sant'Anna, que os encaminhou para Carlos Drummond de Andrade.

Em 1975, Drummond sugeriu a Pedro Paulo de Sena Madureira, da Editora Imago, a publicação do livro de Adélia Prado, cujos poemas considerava fenomenais. No dia 9 de outubro, Drummond publicou uma crônica no Jornal do Brasil ressaltando o trabalho da escritora. O lançamento do livro Bagagem é feito em 1976, estando presentes Antônio Houaiss, Raquel Jardim, Carlos Drummond de Andrade, Clarice Lispector, Juscelino Kubitscheck, Affonso Romano de Sant'Anna, Nélida Piñon e Alphonsus de Guimaraens Filho. Em 1978, é lançado o livro O coração disparado, ganhador do Prêmio Jabuti, da Câmara Brasileira do Livro. No ano seguinte ocorreu sua estreia em prosa com Soltem os cachorros. Diante do sucesso de sua carreira, a escritora decidiu abandonar o magistério, após 24 anos de trabalho.

Em 1981 lançou Terra de Santa Cruz. De 1983 a 1988, exerceu os cargos de chefe da divisão cultural da Secretaria Municipal de Educação e da Cultura de Divinópolis, a convite do prefeito Aristides Salgado dos Santos. Os componentes da banda foi publicado em 1984.

1. Com a colaboração de Cristine Vargas (revista Comunicação \& Educação - ECA/USP e FFLCH/ USP).

2. É autor de inúmeros artigos e livros; dentre estes se destacam: Linguagem e persuasão (Ática, 1994); Comunicação e educação: a linguagem em movimento (SENAC, 2000); Palavras, meios de comunicação e educação (Cortez, 2006). 


$$
\text { comunicação \& educação • Ano XIV • Número } 1 \text { • jan/abr } 2009
$$

No ano de 1988 foi lançado A faca no peito e, em 1991, Poesia reunida. Voltou, em 1993, à Secretaria Municipal de Educação e Cultura de Divinópolis, integrando a equipe de orientação pedagógica na gestão da secretária Teresinha Costa Rabelo. Em 1994, após anos de silêncio poético, Adélia Prado retornou à cena literária com o livro O homem da mão seca. Em 1999, foram lançados Manuscritos de Felipa e Oráculos de maio.

\section{CÉU E TERRA}

Adélia Prado é frequentemente lembrada por expressar o cotidiano e a religiosidade ao longo de sua obra. A escritora, católica confessa, formouse em Magistério, exercendo a profissão de professora durante 24 anos. Casou-se, teve cinco filhos, e em 1976, aos 41 anos, publicou sua primeira obra, o livro de poesias Bagagem.

O cotidiano de Adélia Prado tem como espaço quintais, casas, hortas, cozinhas, salas, igrejas, cemitérios. Nesses espaços são expressos a religiosidade, as conversas entre amigos e familiares, a morte, a saudade do pai e da mãe falecidos, os desejos do corpo, entre outros temas. Sendo o cotidiano da escritora simples, prosaico e caseiro, sua poesia espelha esse universo, fato que produziu o estereótipo da dona de casa provincialmente mineira. Entretanto, a obra de Adélia, ainda que apresente uma superfície de fácil assimilação, é densa de significação.

No universo simplório exposto pela escritora, reside uma oculta beleza. Diante de uma situação ordinária da vida de dona de casa, o leitor deparase com a epifania do Belo e do Divino. Segundo Heller ${ }^{3}$, a vida cotidiana é vida de todo homem e é a vida do homem por inteiro, pelo fato de estarem nelas empenhadas todas as nossas capacidades. Nesse sentido, a obra de Adélia Prado sai de seu mundo particular para atingir o universal, tornando sua história individual em história da humanidade.

As influências mais diretas da escritora são Carlos Drummond de Andrade, Guimarães Rosa e, sobretudo, a Bíblia. A dimensão religiosa de sua poesia vai além da abordagem de assuntos religiosos; sua poética da vivência cotidiana explicita também a vivência religiosa; portanto, sua abordagem é a da experiência religiosa.

Adélia Prado produz uma poesia confessional e transparente. Ela não esconde a fé, tampouco apenas a endossa; em alguns momentos, conta-a, revela-a de forma inabalável; em outros momentos, apresenta dúvidas e divergências. Há ainda um erotismo manifesto entre o profano e o sagrado. São misturados o gozo carnal e o êxtase espiritual.

Outro ponto a ser ressaltado na obra de Adélia Prado é a nova perspectiva que lança sobre a mulher. A autora não recusa os papéis destinados às mulheres, no entanto, manifesta um novo olhar, em que estas cumprem

3. HELLER, Agnes. O cotidiano e a história. Rio de Janeiro: Paz e Terra, 2000. seus papéis sociais sem imposição e opressão. Segundo a crítica, ela apresenta equilíbrio entre o feminismo e o feminino. 
Através da obra de Adélia Prado, a revista Comunicação \& Educação pretende proporcionar ao leitor momentos de fruição de singela, sutil e profunda beleza da poesia que reside em nosso dia-a-dia.

\section{POESIAS}

A seguir serão apresentados quatro poemas que pretendem esboçar algumas das faces de Adélia Prado. Em Com licença poética, a escritora dialoga com o Poema das sete faces, de Carlos Drummond de Andrade, com certa tensão e humor ao tocar na condição da mulher. Em Guia, a poesia é vista como via de salvação, a despeito das instituições e tradições religiosas. Em Moça na cama, numa cena cotidiana com a mãe, são misturados religiosidade e erotismo. Em Leitura, é revelado um momento de sutil epifania, num reencontro com a figura do pai.

\section{Com licença poética}

Quando nasci, um anjo esbelto, desses que tocam trombeta, anunciou: vai carregar bandeira. Cargo muito pesado pra mulher, esta espécie ainda envergonhada.

Aceito os subterfúgios que me cabem, sem precisar mentir.

Não sou feia que não possa casar, acho o Rio de Janeiro uma beleza e ora sim, ora não, creio em parto sem dor. Mas o que sinto escrevo. Cumpro a sina. Inauguro linhagens, fundo reinos — dor não é amargura.

Minha tristeza não tem pedigree, já a minha vontade de alegria, sua raiz vai ao meu mil avô.

Vai ser coxo na vida é maldição pra homem.

Mulher é desdobrável. Eu sou.

\section{Guia}

A poesia me salvará.

Falo constrangida, porque só Jesus Cristo

é o Salvador, conforme escreveu

um homem - sem coação alguma -

atrás de um crucifixo que trouxe de lembrança

de Congonhas do Campo. 
No entanto, repito, a poesia me salvará.

Por ela entendo a paixão

que Ele teve por nós, morrendo na cruz.

Ela me salvará, porque o roxo

das flores debruçado na cerca

perdoa a moça do seu feio corpo.

Nela, a Virgem Maria e os santos consentem

no meu caminho apócrifo de entender a palavra

pelo seu reverso, captar a mensagem

pelo arauto, conforme sejam suas mãos e olhos.

Ela me salvará. Não falo aos quatro ventos, porque temo os doutores, a excomunhão

e o escândalo dos fracos. A Deus não temo.

Que outra coisa ela é senão Sua face atingida

da brutalidade das coisas?

\section{Moça na cama}

Papai tosse, dando aviso de si, vem examinar as tramelas, uma a uma.

A cumeeira da casa é de peroba do campo, posso dormir sossegada. Mamãe vem me cobrir, tomo a bênção e fujo atrás dos homens,

me contendo por usura, fazendo render o bom.

Se me tocar, desencadeio as chusmas,

os peixinhos cardumes.

Os topázios me ardem onde mamãe sabe,

por isso ela me diz com ciúmes:

dorme logo, que é tarde.

Sim, mamãe, já vou:

passear na praça sem ninguém me ralhar.

Adeus, que me cuido, vou campear nos becos, moça de moços no bar, violão e olhos

difíceis de sair de mim.

Quando esta nossa cidade ressonar em neblina, os moços marianos vão me esperar na matriz.

O céu é aqui, mamãe.

Que bom não ser livro inspirado

o catecismo da doutrina cristã,

posso adiar meus escrúpulos

e cavalgar no torpor

dos monsenhores podados. 
Posso sofrer amanhã

a linda nódoa de vinho

das flores murchas no chão.

As fábricas têm os seus pátios,

os muros têm seu atrás.

No quartel são gentis comigo.

Não quero chá, minha mãe,

quero a mão do frei Crisóstomo

me ungindo com óleo santo.

Da vida quero a paixão.

E quero escravos, sou lassa.

Com amor de zanga e momo,

quero minha cama de catre,

o santo anjo do Senhor,

meu zeloso guardador.

Mas descansa, que ele é eunuco, mamãe.

\section{Leitura}

Era um quintal ensombrado, murado alto de pedras.

As macieiras tinham maçãs temporãs, a casca vermelha

de escuríssimo vinho, o gosto caprichado das coisas

fora do seu tempo desejadas.

Ao longo do muro eram talhas de barro.

Eu comia maçãs, bebia a melhor água, sabendo

que lá fora o mundo havia parado de calor.

Depois encontrei meu pai, que me fez festa

e não estava doente e nem tinha morrido, por isso ria,

os lábios de novo e a cara circulados de sangue,

caçava o que fazer pra gastar sua alegria:

onde está meu formão, minha vara de pescar,

cadê minha binga, meu vidro de café?

Eu sempre sonho que uma coisa gera,

nunca nada está morto.

O que não parece vivo, aduba.

O que parece estático, espera.

\section{REFERÊNCIAS BIBLIOGRÁFICAS}

ALVES, José Helder Pinheiro. A poesia de Adélia Prado. Dissertação de Mestrado. São Paulo: FFLCH/USP, 1992.

MOREIRA, Ubirajara Araújo. Adélia Prado: a cotidiana poesia. Tese de Doutorado. São Paulo: FFLCH/USP, 2000.

PRADO, Adélia. Poesia reunida. São Paulo: Siciliano, 1991. 
comunicação \& educação • Ano XIV • Número 1 • jan/abr 2009

\section{Endereço eletrônico}

Adélia Prado. Disponível em: <http://www.releituras.com/aprado_bio.asp >. Acesso em: 15 set. 2008

PINTO, José Nêumane. A mineira Adélia Prado: poesia e prosa com fé no chão. Disponível em: <http://www.jornaldepoesia.jor.br/jneumanne14c.html $>$. Acesso em: 15 set. 2008.

SPALDING, Marcelo. A literatura feminina de Adélia Prado. Disponível em: $<\mathrm{http}: / /$ www.digestivocultural.com/colunistas/coluna.asp? ${ }^{2}$ codigo $=1968>$. Acesso em: 15 set. 2008. 